\title{
Covid-19: "Staggering number" of extra deaths in community is not explained by covid-19
}

\author{
Shaun Griffin
}

London

Only a third of the excess deaths seen in the community in England and Wales can be explained by covid-19, new data have shown.

The Office for National Statistics (ONS) data, ${ }^{1}$ which cover deaths in hospitals, care homes, private homes, hospices, and elsewhere, show that 6035 people died as a result of suspected or confirmed covid-19 infection in England and Wales in the week ending 1 May 2020 (where deaths were registered up to 9 May), a decline of 2202 from the previous week.

Although the number of deaths in care homes has fallen for the second week in a row, more covid related deaths are being reported in care homes than in hospitals and are tailing off more slowly.

However, David Spiegelhalter, chair of the Winton Centre for Risk and Evidence Communication at the University of Cambridge, said that covid-19 did not explain the high number of deaths taking place in the community.

At a briefing hosted by the Science Media Centre on 12 May he explained that, over the past five weeks, care homes and other community settings had had to deal with a "staggering burden" of 30000 more deaths than would normally be expected, as patients were moved out of hospitals that were anticipating high demand for beds.

Of those 30000 , only 10000 have had covid-19 specified on the death certificate. While Spiegelhalter acknowledged that some of these "excess deaths" might be the result of underdiagnosis, "the huge number of unexplained extra deaths in homes and care homes is extraordinary. When we look back ... this rise in non-covid extra deaths outside the hospital is something I hope will be given really severe attention."

He added that many of these deaths would be among people "who may well have lived longer if they had managed to get to hospital."

\section{Underlying causes}

David Leon, professor of epidemiology at the London School of Hygiene \& Tropical Medicine, agreed. "Some of these deaths may not have occurred if people had got to hospital," he said. "How many is unclear. This issue needs urgent attention, and steps taken to ensure that those who would benefit from hospital treatment and care for other conditions can get it."

Also at the briefing was Jason Oke, senior statistician at the Nuffield Department of Primary Care Health Sciences at the University of Oxford, who explained that equivalent data on excess deaths in Scotland ${ }^{2}$ were classified by the underlying cause of death-including dementia, as well as circulatory, cancer, and respiratory causes. In the first week after lockdown a spike in deaths occurred from all causes, but "we now have a return to normality for all except dementia," he explained. He called for the ONS to report on excess deaths in a similar way.

Responding to the latest figures, Jennifer Dixon, chief executive of the Health Foundation think tank, said, “Today's data show that action to tackle the coronavirus pandemic in social care has been late and inadequate, and has highlighted significant weaknesses in the social care system due to decades of neglect and lack of reform. Covid-19 has ultimately magnified the human impact of decades of underfunding in the sector and policy neglect."

In total, England and Wales have recorded 34978 covid-19 deaths from 28 December 2019 to 9 May this year. More than 22600 of the deaths occurred in hospitals and 7400 in care homes.

Correction: On 14 May we corrected the date of the Science Media Centre briefing (12 May, not 21 May).

1 Office for National Statistics. Deaths registered weekly in England and Wales, provisional: week ending 1 May 2020. 12 May 2020. https://www.ons.gov.uk/ peoplepopulationandcommunity/birthsdeathsandmarriages/deaths/bulletins/ deathsregisteredweeklyinenglandandwalesprovisional/weekending1may2020

2 National Records of Scotland. Deaths involving COVID-19, week 18-27 April to 3 May April. 6 May 2020. https://www.nrscotland.gov.uk/news/2020/deaths-involving-covid-19week-18-27th-april-to-3rd-may.

Published by the BMJ Publishing Group Limited. For permission to use (where not already granted under a licence) please go to http://group.bmj.com/group/rights-licensing/ permissions 